\title{
Why Goat Farming in Northern Communal Areas of Namibia Is not Commercialised: The Case of Ogongo Constituency
}

\author{
Cecil Togarepi ${ }^{1}$, Benisiu Thomas ${ }^{1} \&$ Namutenya Hilka Mika ${ }^{1}$ \\ ${ }^{1}$ Department of Agricultural Economics and Extension, University of Namibia, Oshakati, Namibia \\ Correspondience: Cecil Togarepi, Department of Agricultural Economics and Extension, University of Namibia, \\ Ogongo Campus. Private Bag 5520, Oshakati, Namibia. E-mail: ctogarepi@unam.na
}

Received: August 1, 2018

doi:10.5539/jsd.v11n6p236
Accepted: September 17, $2018 \quad$ Online Published: November 29, 2018

URL: https://doi.org/10.5539/jsd.v11n6p236

\begin{abstract}
In Namibia, goat products are not found in the formal markets include retail shops. This is despite several attempts by the government of Namibia to promote goat products in the formal sector. At household level however, goat meat is a delicacy. This study therefore seeks to provide possible reasons for the unavailability of goat products in Northern Namibia focussing on the supply side of the goat market. A structured survey questionnaire was employed among 75 goat farmers in Ogongo Constituency, Omusati Region in North Central Namibia. The data sought included production, offtake and marketing of goats as well as challenges faced. Descriptive statistics were used to analyse the data and multiple linear regression was employed to determine the factors influencing offtake rate. The offtake rate (percent of goats sold) was estimated as $2.8 \%$ from the data, which is very low. The offtake rate was significantly influenced by age of the head of household $(\mathrm{p}<0.01)$, education level of the household head $(p<0.01)$ and marital status $(p<0.01)$. On the other hand, goat production was affected by other challenges such as unavailability of marketing infrastructure, diseases, grazing shortages, and frequent droughts. The implications of these findings on policy include provision of incentives to farmers to sale as well as providing marketing infrastructure. Thus the study recommends the sensitization of communal farmers on economic potential of selling goats to alleviate poverty and to improve livelihoods through income generation.
\end{abstract}

Keywords: formal market, goat production, informal market, marketing challenge, offtake rate

\section{Introduction}

Goats are popular small ruminants kept for meat, milk and hide, manure and traditional rituals as well as to generate cash across the world (Homann, Van Rooyen, Moyo, \& Nengomasha, 2007; Koluman \& Silanikove, 2017). According to FAO ( 2015) there were about 1005603000 billion goats worldwide in 2013 with about 351978256 million from Africa accounting for 35\%. Namibia has only 1968513 which is only $0.5 \%$ of the African goat population (FAO, 2015). The production of goats is mostly dependent on natural pasture as they are browsers that feed mostly on shrubs and tree leaves in adverse environments (Dube, Chakoma, \& Bahta, 2017; Yesufu, Kassali, Aremu, \& Ojo, 2017). Goats can also be utilised to control bush encroachment, as a result unwanted weeds can be reduced and promote the retention of the indigenous grasses (Solaiman, 2007).Thus goats have the ability to be raised successfully under diverse and harsh agro-ecological conditions with poor vegetation found in mountains, deserts and semi-arid regions because they are more resistant to drought because of their unique biological and physiological features (Al-Khaza'leh, Raber, Ogutu, \& Valle-Zarate, 2016; Yesufu, Kassali, Aremu, \& Ojo, 2017). In addition their higher reproductive rate allows populations to recover quickly (Van Rooyen \& Moyo, 2007).

In most African countries small-scale goat farming has been a major source of livelihood for ages, yet little effort exist to explore its full potential through commercialisation (Yesufu, Kassali, Aremu, \& Ojo, 2017). The goat industry has been recognised by governments as having great potential to contribute to household food security and generate income and improved livelihoods for farmers in rural or remote areas (Nyathi, 2008). As a result in situations where formal financial and insurance institutions are absent, goats are "easy to cash" assets (Dossa, Rischkowsky, Birner, \& Wollny, 2008; Hamito, 2004). For instance small-scale farmers, in particular those in rural areas, with little access to land are gradually recognising the potential of goats as a low-cost solution to their poor resource endowments (Nyathi, 2008). In addition, promoting goat production is vital to contribute to risk mitigation, especially in drought-prone areas, and empowerment of vulnerable groups (women, HIV/AIDS 
affected, poor) (Van Rooyen \& Moyo, 2007). Despite the benefits of keeping goats, their productivity and offtake in small-scale production systems remain low in most of the southern African region (Van Rooyen \& Moyo, 2007). Thus improving goat production and better access to markets can go a long way in contributing to enhancing the livelihoods of the rural people especially of the poor in Southern Africa (Nyathi, 2008).

In Namibia the types of breeds of goats found include Boer goats, Angora and Mohair mainly found in the central and southern parts and four (Owambo, Kavango, Caprivi and Kunene) indigenous goats ecotypes found mainly in the Northern Communal Areas (Els, Kotze, \& Swart, 2004). These ecotypes represent distinctive phenotypic characteristics due to their adaptation to the different semi-arid environmental conditions. In 2016, the total number of goats in Northern communal areas were 1228456 which is $62 \%$ of national goat population (Ministry of Agriculture, Water and Forestry, 2017). Goats are especially suited to the semi-arid areas of Namibia due to their ability to adapt to harsh climatic conditions including drought. As stated earlier they also play an important role to improve household food security, incomes and alleviate poverty among rural people especially women and children headed housed holds.

In Namibia the goat markets are both formal and informal. Formal market in this study refers to the market that is officially recorded, where prices are properly determined and sellers publicly advertise their prices on which taxes must be paid. Formal markets for goats in Namibia are poorly developed and in northern communal areas, are almost non-existent. Absence of a formal market for goats is one of the drawbacks that is affecting goats' offtake (Mushedami, Biwa, \& Gaomab, 2008). Thus most subsistence farmers sell their goats informally to friends and other individuals especially during the peak demand festive seasons or to the street vendors that sell okapana (barbequed meat). In northern communal areas farmers sell their goats on a cash need basis whilst in southern and central parts of the country farmers sell through organised markets where information is shared among players for goat locally mainly through auctions and exports to South Africa and Angola. In the informal markets, prices greatly vary on the basis of quality and demand of goat products as well as due to lack of market price information.

In Namibia there has been an unsuccessful attempt to promote goat products formally by introducing products such as goat meat, and milk to consumers in restaurants and retail outlets. These efforts have not produced the desired results and the absence of goat products in the formal market still persist. Thus, linking goat farmers to formal markets remains a challenge and little is known about why goat and goat products are not found in the formal markets. Marketing channels are not adequately developed for the goat industry in Namibia. This study seeks to provide possible reasons for the unavailability of goat products in the formal market in Northern Namibia focussing on the supply side.

\section{Methodology}

The study was conducted in Northern Communal Areas of Namibia (NCA) in Ogongo which is one of the 12 constituencies in Omusati region (Figure 1). The constituency has approximately 19546 residents with 3753 households in the constituency and it is $806.8 \mathrm{~km}^{2}$ in size (Namibia Statistics Agency, 2012). Most of the households in Ogongo keep livestock mostly goats and cattle and they grow rain-fed pearl millet which is their staple food. Fifty six percent (56\%) of the households in Ogongo are female-headed while the $44 \%$ are headed by males and have a literacy rate of $85 \%$ for those 15 years and above (Namibia Statistics Agency, 2012). Omusati has 265446 goats which is $(22 \%)$ of northern communal areas population. Omusati Region has an average annual rainfall of more than $350 \mathrm{~mm}$ and average annual temperature of more than $22^{\circ} \mathrm{C}$. The vegetation type ranges from mopane savanna in the west to forest savanna and woodland in the east. The proportion of households that own livestock is 39\% (Namibia Statistics Agency, 2015). 


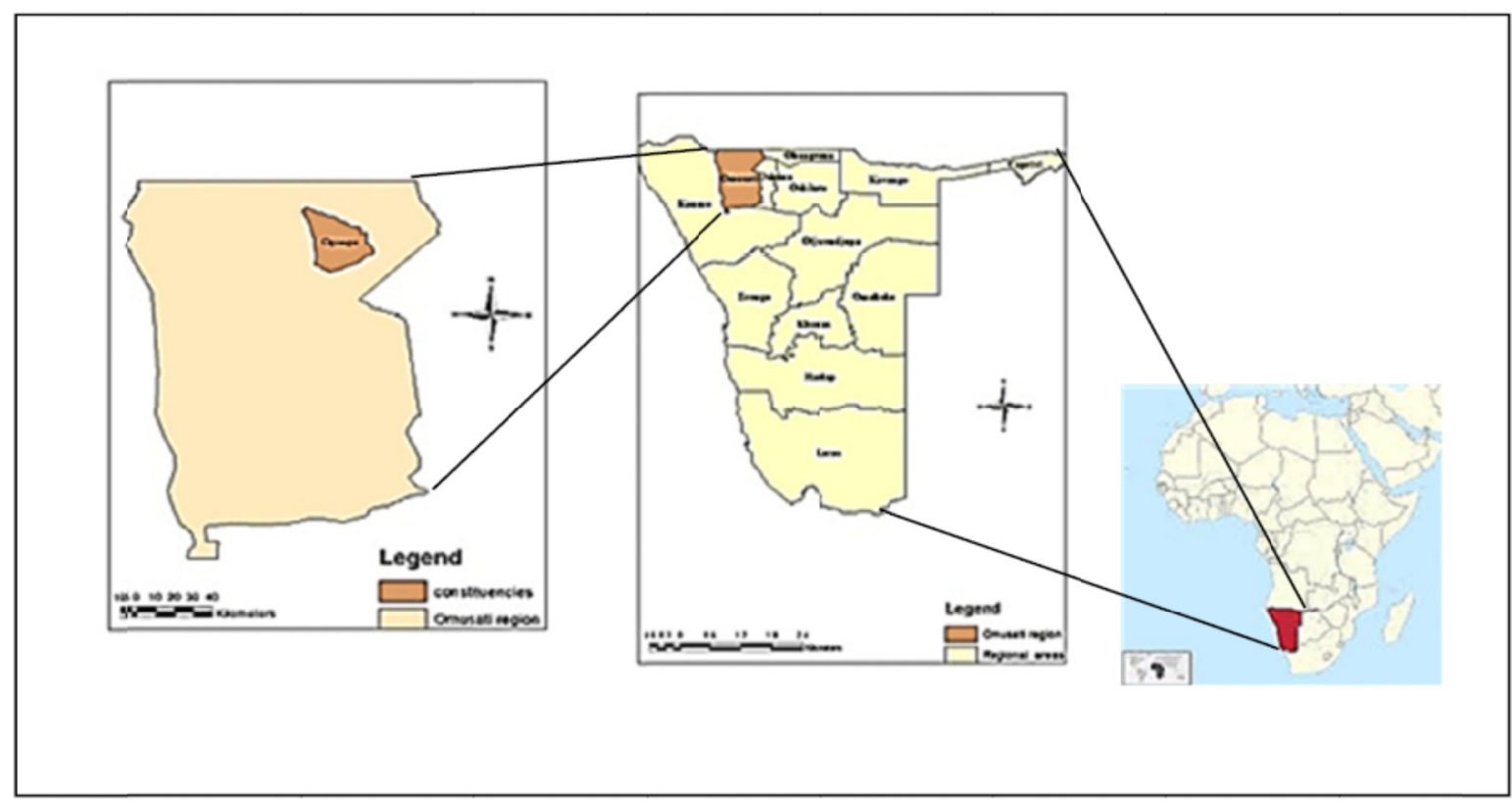

Figure 1. Map of the study area in relation to north central Namibia and Africa

The study was conducted in five villages namely Omanogondjamba $(n=20)$, Onamundindi $(n=17)$, Okeeke $(\mathrm{n}=13)$, Ogongo $(\mathrm{n}=9)$ and Eendjeno $(\mathrm{n}=16)$ in which 75 structured questionnaires were administered. A proportional sampling method was used based on number of households in each village and that was divided by the total households in the five villages. Since the total number of households in the five villages was 407 and 39\% of households own livestock (Namibia Statistics Agency , 2015), the approach was to interview at least $40 \%$ of the households.

Data was collected on household socio-economic characteristics, acquisition and importance of goats, breed, type and number of livestock kept, duration of keeping goat, sales and marketing of goats and the willingness of farmers to produce for the formal goat meat market and challenges faced in production. The questionnaire was tested before the survey started to ensure that all questions were clear to the interviewees and was adjusted based on the comments received. The data was coded and analysed using descriptive statistics for socio-economic characteristics, production and marketing information in Statistical Package for Social Sciences (SPPS) version 21. A multiple linear regression model was used to determine the factors that influence the offtake rate with the hypothesised effect of the variables used in the model as explained in Table 1.

Table 1. Hypothesised effect of the explanatory variable on the dependent variable

\begin{tabular}{lll}
\hline Variable & Description & Expected sign \\
\hline Dependent variable $(\mathrm{Y})$ & $\begin{array}{l}\text { Number of goats sold yearly divided by the number of goats } \\
\text { kept times 100. }\end{array}$ & \\
Explanatory variable & Age in years for the household head & - \\
Age & Number of years of schooling (formal education) & + \\
Education & Means of acquiring cash for household expenditure & - \\
Source of income & 0 if married and 1 if not married & + \\
Marital status & Number of persons in the household & + \\
Household size & Reasons for goat keeping & - \\
Purpose of goat keeping & The way the goats were acquired & $+/-$ \\
Acquisition & Household accessibility to credit & $+/-$ \\
Access to credit &
\end{tabular}




\section{Results and Discussions}

\subsection{Socio Demographic Information}

The key socio-demographic characteristics of surveyed farmers are summarized in Table 2 . About $44 \%$ of the households interviewed were headed by females. Age of the sampled farmers' ranged from 35-84 years and the average age was 50 years, with the majority in the 40-45 age group (31\%) and this shows that youth were the least involved in farming activities. This concurs with findings from a study in South Africa that more than $60 \%$ of young people were not participating in agricultural activities (Cheteni, 2016).

The majority of the respondents had formal education with $46.7 \%$ completing secondary education, $28 \%$ completed primary education, while $12 \%$ and $13.3 \%$ had vocational and tertiary qualification respectively. Thus there was high literacy rate (Motiang \& Webb, 2015) among the respondents which implies that formal education may increase chances of participating or adopting modern agriculture innovations and technologies that would improve agriculture productivity (Adesina, 2016). Male headed households owned more goats than female headed households although female headed households sold more goats. Moreover, households with secondary education owned more goats and also sold more goats than the rest (Table 2).

Table 2. Household socio demographic characteristics

\begin{tabular}{|c|c|c|c|c|}
\hline Characteristics & & $\begin{array}{l}\text { Frequency } \\
\text { (\%) }\end{array}$ & $\begin{array}{l}\text { Number of } \\
\text { goats owned } \\
(\%)\end{array}$ & $\begin{array}{l}\text { Number of } \\
\text { Goats sold (\%) }\end{array}$ \\
\hline \multirow[t]{2}{*}{ Gender } & Male & $42(56)$ & 1486 & 24 \\
\hline & Female & $33(44)$ & 1094 & 31 \\
\hline \multirow[t]{4}{*}{ Education level } & Primary & $21(28)$ & 776 & 12 \\
\hline & Secondary & $35(46.7)$ & 1173 & 27 \\
\hline & Vocational & $9(12.0)$ & 315 & 7 \\
\hline & Tertiary & $10(13.3)$ & 318 & 12 \\
\hline \multirow[t]{4}{*}{ Age } & $30-40$ & $10(13.3)$ & 323 & 14 \\
\hline & $41-50$ & $25(33.3)$ & 885 & 18 \\
\hline & $51-60$ & $21(28)$ & 697 & 16 \\
\hline & $61+$ & $19(25.3)$ & 693 & 10 \\
\hline \multirow[t]{2}{*}{ Marital status } & Single & $24(32)$ & 796 & 29 \\
\hline & married & $51(68)$ & 1786 & 29 \\
\hline Average Family size (head count) & 8 & & & \\
\hline
\end{tabular}

Source: Field data

Note: Number in brackets show percentage (\%)

\subsection{Goat Production}

The main breeds of goats kept by the households are the Owambo ecotype and to a lesser extend the Boer goat and other mixed breeds. The 75 households interviewed had a total of 2067 goats (Table 3). Goats are mainly kept for household meat consumption $(92.7 \%)$, ritual purposes and traditional ceremonies such as weddings and birth of a child (5.3\%) and cash sales (2.7\%). These findings support those of Mahanjana and Cronjé (2000) who found that the main reasons given for keeping goats were household consumption (42\%), slaughter during traditional ceremonies $(35 \%)$ and cash sales $(23 \%)$. 
Table 3. Number of goats owned per village

\begin{tabular}{lll}
\hline Village name & Number of goats kept & \% \\
\hline Omanogondjamba & 584 & 28.3 \\
Onamundindi & 488 & 23.6 \\
Okeeke & 309 & 14.9 \\
Ogongo & 259 & 12.5 \\
Endjeno & 427 & 20.7 \\
Total number of goats owned & $\mathbf{2 0 6 7}$ & $\mathbf{1 0 0 . 0}$
\end{tabular}

Source: Field data

\subsection{Goat Production Challenges}

The major production challenges among the respondents were diseases $(37.9 \%)$, feed shortage $(37.8 \%)$ and predation caused mainly by dogs $(24.3 \%)$. Frequent droughts were the main cause of feed shortage. Feed shortage and poor goat production systems were found to cause low carcass weights in goats (Musara, Chimvuramahwe, Muyati, Chivheya, \& Mwadzingeni, 2013). However other studies found that goats have a higher capacity than other farm raised ruminants to effectively convert some feed sources into milk and meat (Koluman \& Silanikove, 2017) thus are able to survive arid and drought conditions.

Goats were prone to diseases such as tick borne diseases, lumpy skin, fever and internal parasites which were linked to poor and low quality feed causing high mortality. Farmers also complained about plant poisoning caused by wild onion scientifically called Dipcadi glaucum and onyanga in local Oshiwambo language causing a lot of losses. Infectious diseases and parasites are major constraints to communal goat production and are prevalent in many regions of Southern Africa (Gathiori, Athanasiadou, \& Thamsborg, 2006).

Predation is mainly caused by dogs which attack vulnerable kids thus preventing herd growth. In addition, theft of goats is also on the increase in the study area which affects goat numbers and economic losses to the farmers. Studies in Zimbabwe on goat value chain found that diseases, predation and stock theft were major challenges to goat production (Dube, Chakoma, \& Bahta, 2017).

\subsection{Goat Marketing and Offtake}

Only 21 households (28\%) out of the 75 households from the 5 villages sold goats (Table 4). The results suggest that the households that sell goats were predominantly headed by pensioners and females who rely on government grants and remittances thus they tend to sell goats to complement their income to cater sufficiently for their household expenditure. This study showed that $89.5 \%$ of the respondents that sold their goats informally to private buyers who are individuals that buy mostly one goat at a time irregularly, mostly for household ceremonial celebration especially during the festive seasons. The seller informs the private buyers through friends or through mobile phone. The remaining $10.5 \%$ sold their goats through speculators, who resell to other traders or keep the goats in anticipation of price movements to make high profits. The farmers indicated that they use these channels because they are the only available channels (47.4\%) and also due to irregular sales pattern as sales are done when there is need for cash $(52.6 \%)$. This is similar to findings in South Africa where goat market is driven by the informal trade and speculators due to absence of formal marketing structures (Directorate Marketing, 2014).

The number of goats sold from a single household ranged between 1 and 7 . On average a goat selling price was N\$ 837.00 (USD62.60), the highest selling price recorded for a goat was N\$1000 (USD74.80) and this was earned through private buyers. Motiang and Webb, (2016) argued that the high price associated with out of hand (private buyers) sales may be due to ability to negotiate prices between buyers and sellers. Similarly, in South Africa the high prices were attributed to shortage of goats in the market and high demand (Directorate Marketing, 2014). Nevertheless, households that sold their goats to speculators expressed dissatisfaction with the unit price. The relatively higher sales through private buyers suggest that farmers in the study area could be selling their goats to address urgent financial needs. However, the overall low proportion of sales of goats in the study area could be attributed to the unreliability of this market and inconsistence in supply of goats and selling as need arises.

Although female headed household own about 2 goats less than male headed households, they sell more goats 
(3.1) than male headed households (2.4) and are willing to sell even more goats (7.1) compared to the male headed households (2.6). This could indicate the increase in need for cash for female headed households as they may not have spousal support or may not be receiving remittances that are important for household expenditure.

Table 4. Proportion of households that sell goats in each village

\begin{tabular}{|c|c|c|}
\hline Village name & $\begin{array}{l}\text { Number of households } \\
\text { interviewed }\end{array}$ & $\begin{array}{l}\text { Number of households } \\
\text { selling goats }(\%)\end{array}$ \\
\hline Omanogondjamba & 20 & $6(30)$ \\
\hline Onamundindi & 17 & $6(35)$ \\
\hline Okeeke & 13 & $5(38)$ \\
\hline Ogongo & 9 & $3(33)$ \\
\hline Endjeno & 16 & $1(6.3)$ \\
\hline Total & 75 & $21(28)$ \\
\hline
\end{tabular}

\section{Source: Field data}

Note: Number in brackets show percentage (\%)

Table 5 presents off-take rate of individual households, which was calculated using the method adopted from Enkono, et al. (2013) study, where by goats' off-take rate was calculated as the number of goats sold as a percentage of total goats kept. The average offtake of the respondents was $2.8 \%$ which is very low.

Table 5. Number of goats sold per village in the past 12 months

\begin{tabular}{lll}
\hline Village name & Number of goats kept & Number of goats sold (\%) \\
\hline Omanogondjamba & 584 & $22(4)$ \\
Onamundindi & 488 & $14(2.9)$ \\
Okeeke & 309 & $15(4.9)$ \\
Ogongo & 259 & $6(2.3)$ \\
Endjeno & 427 & $1(0.2)$ \\
Total & $\mathbf{2 0 6 7}$ & $\mathbf{5 8 ( 2 . 8 )}$ \\
\hline
\end{tabular}

Source: Field data

Note: Number in brackets show percentage (\%)

\subsection{Factors That Influence Goats' off Take Rate}

A forward selection method was employed to select the best variables and to remove redundant variables, and cater for the issue of confounding variables. Occam's razor principle states that among several plausible explanations for a phenomenon, the simplest is best. The multiple linear regression model selected only 3 independent variables that were significant $(p<0.05)$, namely age of the head of household, education which is captured as the number of years of schooling and marital status (Table 6).

The overall model fit summary, the adjusted $\mathrm{R}$ square is equal to 0.58 (Table 6). Adjusted $\mathrm{R}$ square measures the proportion of the total variability in the dependent variable that is explained by the independent variables in the model. Therefore, $58 \%$ of the total variability in the goats' off-take rate was explained by the model. This implies that about $58 \%$ of the total variation in the goats' off-take rate was due to the difference in the age of farmers, education and marital status.

The F-statistic results are significant at $p<0.001$, thus the null hypothesis that states that the model has no explanatory power is rejected. The null hypothesis of the t- statistic states that the coefficient of the independent variables is zero, in other words none of the independent variable helped to predict the dependent variable. The study fails to accept the null hypothesis of the t-test is because all the 3 explanatory variables (age, education and 
marital status) which were fed into the model were found to be significant at $1 \%$ level. As hypothesized age has a negative influence on the goats' off-take rate, thus according to the unstandardized coefficients results, one year increase in the age of a farmer will decrease the off-take rate by $1 \%$. This is because older farmers are likely not to sell goats because they hold onto their livestock for prestige. Furthermore this study found out that about $95 \%$ of households that sold goats are aged from 35 to 40, these findings are in line with a study by Homann, et al. (2007) whose findings were that heads of households in the productive age group and literate households tended to sell more goats.

The unstandardized coefficient of education is 0.87 , this means that 1 year increase in the education of a farmer will result approximately $1 \%$ increase in goats off-take rate. More than $60 \%$ of farmers who sold goats have at least secondary education which is 12 years of schooling, meaning the higher the number of schooling years the higher the off-take rate. According to Tchale, (2009) both age and education levels of household heads have an impact on livestock production efficiency, thus low off-take rates can be attributed to poor production efficiency which may have emanated from old age and low level of education .On the contrary Kifle, (2014) in his study on the assessment of the performance of the goat marketing system in Afar region of Ethiopia, found that elementary school is sufficient to perform goat trading which represented the majority of goats' traders in the study area.

Table 6. Multiple linear regression results

\begin{tabular}{lll}
\hline Independent variable* & Unstandardized Coefficients) & p-values* \\
\hline Age & -0.506 & 0.000 \\
Marital status & -1.66 & 0.006 \\
Education & 0.873 & 0.005 \\
Intercept & & 0.001 \\
R2 & 0.864 & 0.000 \\
Adjusted R2 & 0.537 & \\
Prob. (F-statistic) & & 0.001 \\
\hline
\end{tabular}

Source: Field data

Significance level at 0.1

Marital status which was also found to be significant has an unstandardized coefficient of -1.66 . This means that there is a decrease of approximately $2 \%$ in the goats' off-take rate if a farmer is single. Thus, the implication is that married farmers can be more efficient in goats' production than single farmers which could be attributed to collective decision making and increased household needs for cash income and thus their increased off-take rate.

Source of income was found to be statistically insignificant in this study because majority of households (37\%) depend on income from employment outside agriculture, while $21.3 \%$ depend on social grant, remittances and small business serve as main sources of income for $18.7 \%$ of the households and only $1.3 \%$ and $2.7 \%$ depend on sales of livestock and sales of crops respectively. These findings are against Motiang and Webb (2015) whose results showed that most farmers relied on sales of livestock.

\subsection{Marketing Challenges}

Farmers that choose to explore other markets closer to urban areas bring their own goats and wait for long periods to sell their goats (Figure 2). Some of the speculators buy the goats from farmers and then bring these goats to the urban areas for resale at higher prices. The majority $(30 \%)$ of farmers who sell goats indicated inconsistency in supplying goats to the buyer as an obstacle to the efficient marketing of goats. Musara, et al.(2013) argued that small stock marketing has remained largely informal because of failure to maintain a constant supply of goat meat (Chevon) to the supermarket chains. This concurs with the current situation whereby in Namibia there is no goat meat in the formal markets like supermarkets. Inadequate and inefficient transport are cited by Mahanjana and Cronjé (2000) who maintained that poor marketing of small stock stem off from problems of transportation of goats to the abattoirs. Furthermore in cases where cattle haulage trucks are used to transport goats the same fee is charged for both goats and cattle transportation marking it more expensive to transport small ruminants than cattle. In the case of limited resources, cattle always take priority, putting goats' 
farmers at a disadvantage.

Some farmers have no information about the availability of organized markets, thus they mostly sell to individual buyers which take place at the farm gate, and an equal percentage of farmers are dissatisfied with the current market infrastructure calling them poorly equipped and not suitable for the sales of small stock. While only $12.5 \%$ of farmers reckoned that low selling prices is the main problem as far as goats selling is concerned.

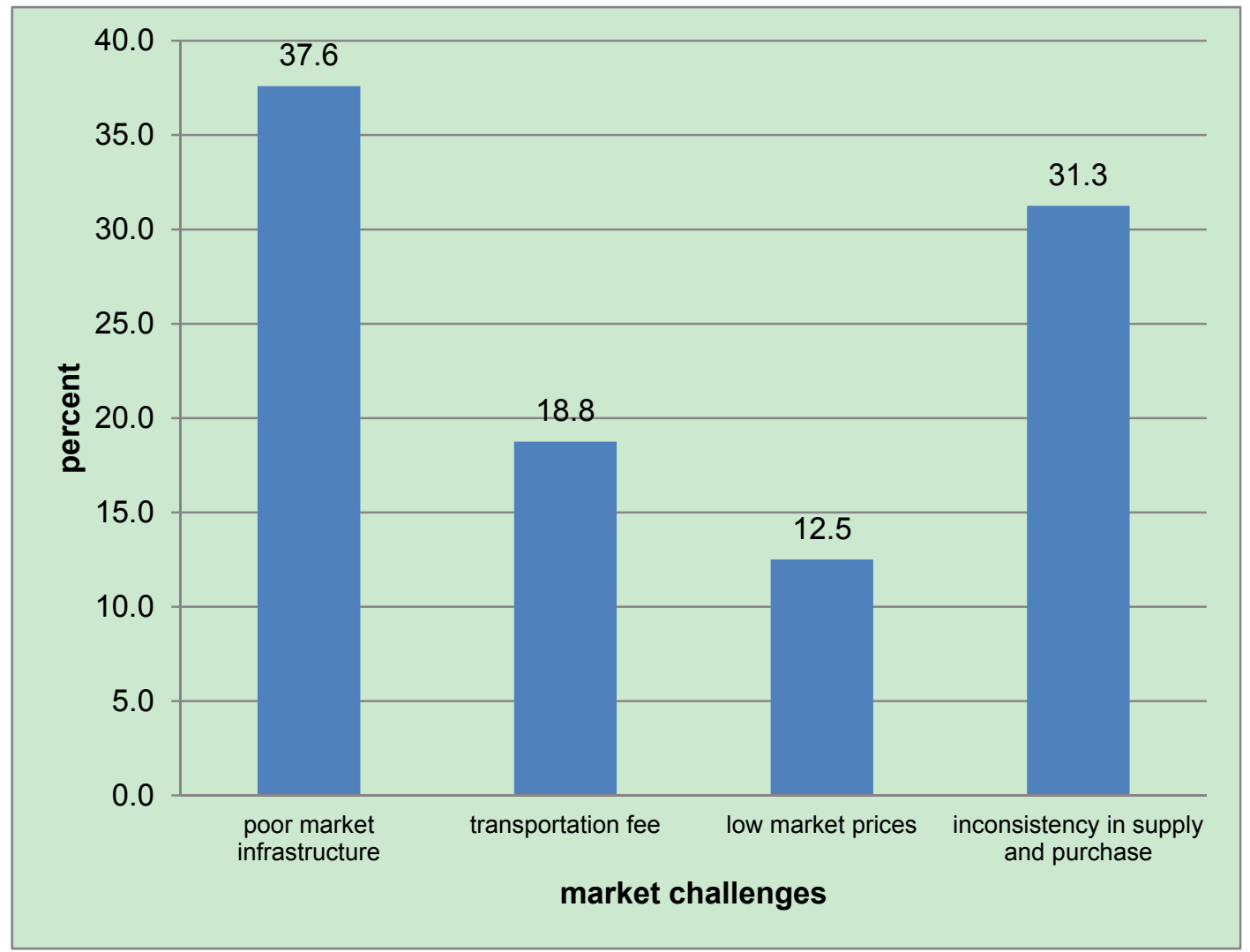

Figure 2. Marketing challenges faced by goat farmers

\subsection{Implications of Findings on Availability of Goat Products in the Formal Retail Markets}

The findings from the study indicate that households own a total of 12 to 42 goats and sale between 1 to 7 goats per household. However, male headed households owned more goats than female headed households but the female headed households sold more goats and are willing to sell even a higher number compared to the male headed households. Thus goats in northern communal areas of Namibia are mainly kept for household consumption and not necessarily for commercial purposes which may be the reason for fewer goats being sold. Any strategy or intervention that maybe employed to improve goat production and marketing should consider focussing production awareness and training on female headed households while marketing awareness and training should focus more on the male headed households as they sale less goats. Moreover, in a semi-arid environment of Omusati and many parts of Namibia frequently affected by drought, it is suggested that more farmers diversify their livestock by incorporating goats as they are more resilient to drought since they are able to survive in harsh conditions and limited pasture unlike cattle.

The study found that there is no formal market for goat products in Northern communal areas of Namibia as goats are sold live to individuals and traders. To address the absence of the formal market, there is need to address the entire supply chain of the goat industry starting with production, marketing and consumption. In the downstream of the supply chain, there are production challenges while upstream there are opportunities for supply of goat products, provision of organized formal markets and incentives for increased goat production might increase sales of goats and eventually warranty formal markets. Implications of this on policy include provision of incentives such as subsidies on goat production and prices as well as establishment of marketing infrastructure for goats as well as promotion of goat products in the formal market which may increase goat offtake. However there is need to investigate further the absence of the goat products in the formal markets from the demand side. 
However, it is important to understand the socio cultural context of goat farming so that any recommendations may not be resisted but complement and build upon the current practices. Goats are seen as alternative to cattle in changing environments as they are better adapted to limited grazing thus improved goat production management would enable increased productivity hence to be encouraged for livelihood sustainability in light of climate change.

\section{Conclusion}

The off-take rate for goats is low. Age, number of years of schooling (education) and marital status were significantly found to influence the number of sales of goats (offtake). Main reasons of goats farming were influenced by socio demographic characteristics of farmers such as traditional beliefs, thus they differ from one region to another. Communal goats farming sector is characterized by challenges which are a synergy of both production and marketing factors, including underdeveloped and poor market infrastructure. There is lack of formal market for goats; therefore most of the farmers (89.5\%) depend on sales at farm gate. Goat meat is widely consumed in Namibia and thus its absence in the formal market remains a paradox which needs further investigation.

\section{References}

Adesina, T. K. (2016). Determinants of Participation in Youth-in-Agriculture Programme in Ondo State, Nigeria. Journal of Agricultural Extension.

Al-Khaza'leh, J., Raber, C., Ogutu, J. O., \& Valle-Zarate, A. (2016). Goat breeds performance under different farming systems and conditions of water availability in Karak Governorate. Jordan Journal of Agricultural Sciences, 441-488.

Cheteni, P. (2016). Youth Participation in Agriculture in the Nkonkobe District Municipality, South Africa. Journal of Human Ecology, 207-213. https://doi.org/10.1080/09709274.2016.11907025

Directorate Marketing. (2014). A PROFILE OF THE SOUTH AFRICAN GOAT MARKET VALUE CHAIN. Deaprtment of Agriculture, Forestry and Fisheries.

Dossa, L., Rischkowsky, B., Birner, R., \& Wollny, C. L. (2008). Socioeconomic determinants of keeping goats and sheep by rural people in Southern Benin. Agriculture and Human Values, 581-592. https://doi.org/10.1007/s10460-008-9138-9

Dube, S., Chakoma, I., \& Bahta, S. (2017). Analysis of the goat value chain in Beitbridge district of Zimbabwe. Nairobi: International Livestock Research Institute.

Els, J., Kotze, A., \& Swartz, H. (2004). Genetic diversity of indigenous goats in Namibia using microsatellite markers: preliminary results. South African Journal of Animal Science, 65-67.

Enkono, S. G., Kalundu, K., \& Thomas, B. (2013, August 30). Analysis of factors influencing cattle off-take rate and marketing in Ndiyona constituency of Kavango region, Namibia. Journal of Agricultural Extension and Rural, 5(9), 201-206.

FAO. (2015). FAO Statistical Pocketbook World food and agriculture. Rome: FAO.

Gathiori, J. B., Athanasiadou, S., \& Thamsborg, S. M. (2006). Use of plants in novel approaches for control of gastrointestinal helminths in livestock with emphasis on small ruminants. Vaet Parasitol, 139(4), 309. https://doi.org/10.1016/j.vetpar.2006.04.021

Hamito, D. (2004). Sheep and Goat production handbook for Ethiopia. USAID.

Homann, S., Van Rooyen, A. F., Moyo, T., \& Nengomasha, Z. (2007). Goat production and marketing: Baseline information for semi arid Zimbabwe. ICRISAT.

Kifle, Z. (2014). Assessment of the performance of the goat marketing system in afar region, Ethiopia. Makelle University, Department of Management. Makelle: Makelle University, Ethipioa.

Koluman, D. N., \& Silanikove, N. (2017). The advantages of goats for future adaptation to Climate Change: A conceptual overview. Small Ruminant Research.

Mahanjana, A. M., \& Cronjé, P. B. (2000). Factors affecting goat production in a communal farming system in the Eastern Cape region of South Africa. South African Journal of Animal Science, 30(2), 149-154. https://doi.org/10.4314/sajas.v30i2.3864

Ministry of Agriculture, Water and Forestry. (2017). Directorate of Veterinary Services . Windhoek: MAWF.

Motiang, D. M., \& Webb, E. C. (2015). The influence of households characteristics on cattle off-take rates in the 
North West Province of South Africa. Livestock Research for Rral Development, 28(6), 300-307.

Musara, J. P., Chimvuramahwe, J., Muyati, V., Chivheya, R., \& Mwadzingeni, L. (2013). Why not commercial goat production? exploring rural communities' preference for livestock enterprises. Case of Matsai communal area, Zimbabwe. E3 Journal of Agricultural Research and Development, 3(3), 30-31. Retrieved April 25, 2016, from http://www.e3journals.org/cms/articles/1369753850_Musara\%20et\%20al.pdf

Mushedami, P., Biwa, B., \& Gaomab, M. (2008). Unleashing the potential of the agricultural sector in Namibia. Windhoek: Bank of Namibia. Windhoek: Bank of Namibia.

Namibia Statistics Agency . (2015). Namibia Agricultural Census. Windhoek: Namibia Statistics Agency .

Namibia Statistics Agency. (2012). Population and Housing Census. Windhoek: Namibia Statistics Agency.

Nyathi, N. (2008). Context of the goat sector in Zimbabwe. Enhancing incomes and livelihoods through improved farmers practices on goat production and marketing" Proceedings of a workshop organised by goat forum Bulawayo, Zimbabwe 2-3 October 2007. ICRISAT.

Solaiman, S. G. (2007). Assessment of the meat goat industry and outlook for U. S. small framers . Tuskegee.

Tchale, H. (2009). The efficiency of smallholder agriculture in Malawi. African Journal of Agricultural and Resource Economics, 139, 101-121.

Van Rooyen, A. F., \& Moyo, T. (2007). Goat production and marketing: Baseline information for semi-arid Zimbabwe. technical Report. South African Land Observatory, International Crop Research institute for the Semi Arid Tropics.

Yesufu, O. A., Kassali, R., Aremu, F. J., \& Ojo, M. O. (2017). Market Analysis of smallholder goat enterprise under tropical conditions. Agricultura Tropica Et Sutropica, 121-127.

\section{Copyrights}

Copyright for this article is retained by the author(s), with first publication rights granted to the journal.

This is an open-access article distributed under the terms and conditions of the Creative Commons Attribution license (http://creativecommons.org/licenses/by/4.0/). 